\title{
Źródła do badań nad ochronkami jako instytucjami opiekuńczo-wychowawczymi w Królestwie Polskim w XIX i na poczqtku XX wieku
}

\section{Sources for Research on Orphanages \\ as Educational Care Institutions in the Kingdom of Poland in the $19^{\text {th }}$ and Early $20^{\text {th }}$ Centuries}

\begin{abstract}
ABSTRAKT
Przedmiotem badań niniejszego artykułu sq ochronki i ich miejsce w systemie opiekuńczo-wychowawczym w Królestwie Polskim w dobie zaborów. Były one zakładane poczqłkowo przez towarzystwa dobroczynne, później także przez inne organizacje społeczne, gminy wyznaniowe, zgromadzenia zakonne oraz osoby prywatne. Zdecydowany wzrost liczby ochronek w miastach i na wsiach Królestwa miał miejsce na poczqtku XX wieku. Problem ten nie jest dokładnie zbadany przez historyków i pedagogów, tymczasem zachowało się wiele źródeł, które przekazuja informacje na temat okoliczności i zasad zakładania oraz funkcjonowania ochronek. Celem tekstu jest wskazanie najważniejszych grup źródeł
\end{abstract}

SLOWA KLUCZOWE ochronka, działalność opiekuńczo-wychowawcza, źródła, Królestwo Polskie

\section{KEYWORDS}

orphanage, educational care activity, sources, Kingdom of Poland

SPI Vol. 19, 2016/2

ISSN 2450-5358

e-ISSN 2450-5366 DOI: 10.12775/SPI.2016.2.013

Raporty z badań 
historycznych, przydatnych w badaniach nad tym tematem. Sq to m.in. materiały archiwalne, zawarte w Archiwum Głównym Akt Dawnych oraz w archiwach państwowych. Ważnq kategoriq źródłowq sq monografie polskich społeczników i intelektualistów, propaguiqqce zakładanie placówek opiekuńczo-wychowawczych dla dzieci. Dużq wartość w badaniach nad ochronkami maja źródła epistolograficzne i memuarystyka, tworzone przez założycieli, pracowników i wychowanków ochronek. Wiele informacji na temat działalności ochronek znajduje się w pamiętnikach, dziennikach i wspomnieniach, z których część wydano drukiem, część pozostaje w zasobach archiwalnych. Szczególnie wartościowq kategoriq źródeł jest czasopiśmiennictwo. Na łamach prasy społeczno-kulturalnej, fachowej, wyznaniowej, kobiecej oraz w codziennych gazetach zamieszczano sprawozdania z działalności konkretnych placówek oraz artykuły na temat znaczenia ochronek w modernizacji systemu opieki i wychowania oraz stosowanych w nich metodach i formach pracy.

\section{ABSTRACT}

The subject of this article are orphanages and their place in the educational care system of the Kingdom of Poland at the time of the Partitions. Initially, they were established by charities, but later also by other social organisations, religious communities, congregations and individuals. A great increase in the number of orphanages in towns and villages of the Kingdom took place in early $20^{\text {th }}$ century. This issue has not been thoroughly investigated by historians and educationists, and at the same time, numerous sources were preserved which convey information on the circumstances and principles of the establishing and functioning of orphanages. The aim of this article is to indicate the most important groups of historical sources, which could be useful in research into this topic. They include archival materials collected in the Central Archives of Historical Records and in state archives. An important source category are the monographs of Polish social activists and intellectuals which propagated the need to establish educational care facilities for children. Epistolographic sources and memoirs written by founders, employees and children raised in orphanages also present high value for research into this topic. A lot of information concerning the operation of orphanages is found in journals, diaries and memoirs, of which some were published and some still remain in archival records. A particularly valuable category of sources is the periodical press. Social and cultural, professional, religious periodicals, women's press and daily newspapers included reports from specific institutions as well as articles on the importance of orphanages in the modernisation of the system of educational care and on the methods and forms of work applied there. 


\section{Warunki rozwoju ochronek na terenie Królestwa Polskiego w XIX i XX wieku}

Przedmiotem rozważań w niniejszym artykule są ochronki, będące miejscami opieki i wychowania dzieci z najuboższych środowisk w miastach i na wsiach. Ich powstawanie było swoistym signum temporis XIX-wiecznego życia społecznego. Instytucjonalne formy opieki nad dziećmi rozwijały się w całej Europie, towarzyszyły przemianom społeczno-gospodarczym, demograficznym i kulturowym. Dotyczyło to także ziem polskich. Celem artykułu jest przedstawienie źródeł, które mogą służyć do analizy działalności ochronek w Królestwie Polskim. Intensywny rozwój tych instytucji, szczególnie w ostatnich dekadach XIX i pierwszych latach XX wieku, był paralelny do przeobrażeń związanych $\mathrm{z}$ procesami industrializacji i urbanizacji z jednej strony, $z$ drugiej - do transformacji społecznej wynikającej ze zmian pouwłaszczeniowych. W pierwszym okresie ochronki powstawały głównie w największych miastach, do których napływała ludność szukająca zatrudnienia w przemyśle. Miały zapewniać wielogodzinną opiekę i wychowanie dzieciom ubogich, pracujących rodziców; były tym bardziej potrzebne, że w dobie intensywnego rozwoju przemysłu w wielu wypadkach koniecznością było podejmowanie pracy zarobkowej również przez matki. W niniejszym tekście nie analizuję ochronek, które były wyłącznie miejscami całościowej opieki nad dziećmi osieroconymi. I takie bowiem placówki nazywano ochronami lub ochronkami, przy czym nazwy te stosowano zamiennie, podobnie jak w przypadku instytucji opieki o charakterze przedszkolnym. Na przełomie XIX i XX wieku powstało wiele osobnych domów dla osieroconych dzieci, co doprowadziło do rozdzielenia i specjalizacji placówek; mianem ochronek określano z czasem tylko miejsca częściowej opieki, przeznaczone dla dzieci rodziców zajętych pracą zarobkową.

Warto krótko przypomnieć historię zakładania ochronek w Królestwie Polskim w dobie zaborów ${ }^{1}$. Pierwsza tego rodzaju instytucja została otwarta w 1839 roku w Warszawie dzięki zabiegom Teofila Janikowskiego. W 1841 roku w Warszawie działały cztery ochronki,

1 Szerzej na ten temat piszę w pracy Spoteczeństwo Królestwa Polskiego wobec patologii spotecznych w latach 1864-1914, Łódź 2016, s. 285-300. 
w roku 1847 było ich siedem, w 1863 -14. Prowadzenie i zakładanie kolejnych zakładów leżało w gestii Wydziału Ochron, utworzonego przy Warszawskim Towarzystwie Dobroczynności. W kolejnych latach Towarzystwo otworzyło szereg nowych placówek; w 1914 roku pod jego zarządem pozostawały 42 ochronki. Niektóre z nich miały więcej niż jeden oddział, zatem miejsc opieki było de facto więcej. Za przykładem Warszawskiego Towarzystwa Dobroczynności poszły towarzystwa dobroczynne w całym Królestwie. Rozwijały się one szczególnie intensywnie w ostatnim ćwierćwieczu XIX i na początku XX wieku, prowadziły przede wszystkim działalność opiekuńczą, socjalną i oświatowo-wychowawczą. Jednym z najważniejszych obszarów ich działań było zakładanie instytucji opiekuńczych i edukacyjnych dla dzieci, w tym - ochronek. Od 1815 roku działało Lubelskie Towarzystwo Dobroczynności (Warszawskie Towarzystwo Dobroczynności założono rok wcześniej). W ostatnich trzech dekadach XIX wieku powstały towarzystwa dobroczynności we wszystkich pozostałych miastach gubernialnych (w Piotrkowie, Kaliszu, Kielcach, Radomiu, Siedlcach, Płocku, Łomży i Suwałkach), dużych przemysłowych miastach powiatowych (w Łodzi, Częstochowie, Pabianicach, Będzinie, Ostrowie Mazowieckim) oraz w innych miastach i osadach (Tomaszów, Ozorków). W latach 1901-1914 założono towarzystwa dobroczynności w wielu innych miastach Kongresówki. Ich rozwój sprzyjał powiększeniu liczby ochronek, bowiem niemal każde towarzystwo, przyjmując zasadę pożyteczności i prymarności opieki instytucjonalnej nad dziećmi, podejmowało działania mające na celu założenie tego rodzaju placówki już w pierwszym okresie swej działalności. Organizatorami ochronek były także gminy wyznaniowe, w tym katolickie, ewangelickie, mariawickie i żydowskie. Często inspiratorami założenia ochronki byli duchowni, czasami inicjatywa wychodziła od świeckich członków wspólnot religijnych. W zakładanie i prowadzenie ochronek, zwłaszcza na wsiach i w małych miasteczkach, angażowały się zgromadzenia bezhabitowe, zakładane przez ojca Honorata Koźmińskiego².

2 Por. M.H. Mazurek, Powstanie i rozwój ukrytych zgromadzeń bt. Honorata Koźmińskiego w latach 1874-1908, oprac. H.I. Szumil, Sandomierz 2009, s. 254-297. 
Istotną rolę w organizowaniu nowych placówek opiekuńczo-wychowawczych dla małych dzieci odegrały również zakładane na początku XX wieku różnego rodzaju towarzystwa społeczne; ich powołanie lub legalizację umożliwiło wprowadzenie w marcu 1906 roku prawa zezwalającego na funkcjonowanie związków i stowarzyszeń. Niektóre organizacje miały lokalny zasięg, kilka prowadziło działalność na terenie całego Królestwa. Rudymentarne znaczenie miała działalność zalegalizowanej w 1906 roku Polskiej Macierzy Szkolnej, która założyła ponad 300 ochronek. W roku 1907 zalegalizowano Związek Katolicki, który podejmował rozmaite działania społeczno-gospodarcze i wychowawczo-oświatowe, w tym zakładanie ochronek. Wiele ochronek prowadziło założone w 1906 roku, a zalegalizowane rok później, Towarzystwo Opieki nad Dziećmi. Stowarzyszenie to najbardziej efektywnie działało w Warszawie; w kilku innych miastach Królestwa założono jego oddziały terenowe. Zajmowało się organizacją działań opiekuńczo-oświatowych dla dzieci najuboższych i zaniedbanych, m.in. poprzez zakładanie ochronek ${ }^{3}$. Jako przykład niewielkiego, lokalnego stowarzyszenia można wymienić działające od 1900 roku Towarzystwo Opieki nad Biednymi Dziećmi w Zgierzu, prowadzące ochronkę dla dzieci robotników ${ }^{4}$. Osobną grupę stanowiły ochronki przyfabryczne, które zaczęły powstawać na przełomie XIX i XX wieku w dużych ośrodkach przemysłowych. I tak, np. w 1875 roku została założona wyróżniająca się liczbą miejsc ochronka w Żyrardowie, która zapewniała opiekę ponad 1000 dzieci5 ${ }^{5}$.

O ile w XIX wieku ochronki zakładano głównie w miastach gubernialnych, powiatowych i osadach przemysłowych, o tyle na początku wieku XX miał miejsce szybki rozwój ochronek w małych miasteczkach, osadach i na wsiach. Szczególnie intensywny przyrost liczby placówek nastąpił około 1905 roku. Ważną rolę w zapewnieniu opieki dzieciom na wsiach odegrały niewielkie ochronki przyfolwarczne, zakładane przez ziemian. Wzrost liczby ochronek na wsiach nastąił po

3 Por. Archiwum Główne Akt Dawnych (dalej w skrócie: AGAD), Kancelaria Generał-Gubernatora Warszawskiego, sygn. 8012.

4 Por. Archiwum Państwowe w Łodzi, Rząd Gubernialny Piotrkowski, Kancelaria Prezydialna, sygn. 294; Z. Pietkiewicz, Opieka spoteczna. Dzieci, „Prawda” 1900, nr 47, s. 558.

5 Por. Kalendarz Informacyjno-Encyklopedyczny na rok przestępny 1904, Warszawa 1904, s. 538. 
rewolucji 1905 roku. Znaczna część tego rodzaju placówek działała pod auspicjami Zjednoczonego Koła Ziemianek, zalegalizowanej w 1907 roku organizacji, która zachęcała kobiety $\mathrm{z}$ warstwy ziemiańskiej do aktywności społecznej, m.in. poprzez zakładanie ochronek, prowadziła kursy dla ochroniarek, współpracowała z Polską Macierzą Szkolną.

W XIX i XX wieku ochronki zdobyły trwałe miejsce w organizowanym głównie $\mathrm{z}$ inicjatyw społecznych systemie opiekuńczo-wychowawczym. Ich działalność i rola były przedmiotem badań, ale zagadnienia te z pewnością zasługują na dalsze studia, tym bardziej, że liczne źródła archiwalne i drukowane umożliwiają przeprowadzenie szczegółowych analiz historyczno-pedagogicznych. W dalszej części artykułu przedstawione zostaną typy źródeł, które mogą być wykorzystane w badaniach poświęconych temu zagadnieniu oraz najczęściej poruszane w nich problemy.

\section{Działalność ochronek w świetle źródeł normatywnych, sprawozdawczych i memuarystycznych}

Informacji na temat okoliczności założenia, zasad organizacji, źródeł finansowania, warunków lokalowych, metod pracy z dziećmi w ochronkach dostarczają rozmaite kategorie źródeł. Szczególną wartość mają materiały archiwalne, w których zawarte są różnego rodzaju informacje o funkcjonowaniu placówek dla dzieci. W okresie do 1870 roku instytucje dobroczynne, które m.in. zakładały ochronki, podlegały nadzorowi utworzonej w roku 1832 Rady Głównej Opiekuńczej ${ }^{6}$. Ocalałe akta własne tej instytucji przechowywane są w Archiwum Głównym Akt Dawnych w Warszawie. Wśród wyróżnionych działów znajduje się dział obejmujący akta sal ochron dla dzieci, głównie z guberni radomskiej, zawierający przede wszystkim dane dotyczące administracji i funduszów ${ }^{7}$. Analiza tej grupy dokumentów pozwala na zbadanie m.in. problemów organizacyjnych i kadrowych. Rada Główna Opiekuńcza miała wiele zastrzeżeń do działalności lokalnych ochronek. I tak np. żądano wyjaśnień co do sytuacji dozorczyni ochronki w Radomiu. Rada powiatowa donosi-

6 Radzie Głównej Opiekuńczej podlegały Rady Szczegółowe nadzorujące poszczególne placówki.

7 Por. AGAD, Rada Główna Opiekuńcza, sygn. 60-73. 
ła, że pracująca tam Tekla Łubieńska „mająca nadzór nad dziećmi w Sali ochrony w Radomiu utrzymywanemi żadnej oddzielnej etatowej pensyi nie pobiera, lecz pełni te obowiązki jako uboga wdowa

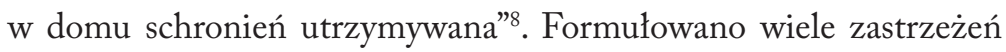
do dokumentów dotyczących wydatków w ochronkach. W 1870 roku wielokrotnie pisano o nieprawidłowościach w dokumentacji finansowej placówki w Suwałkach, podkreślając, że mimo licznych upomnień „nie złożono żadnych dowodów ani kwitów dostarczycieli lub rzemieślników na usprawiedliwienie następujących wydatków: na żywność, opał, odzież, bieliznę, utrzymanie lokalu, ciężary, czystość, sprawienie utensyliów, ich reparacye i jedynie złożono dwa reyestra tych wydatków przez dozorczynię ochrony Krasienską [Krasieńską] opisane które to wydatki ona sama spełniała i wypłacała bez żadnego upoważnienia Rady Szczegółowej”’.

Jak wspomniano, istotną rolę w zakładaniu ochronek pełniły towarzystwa dobroczynne. Materiały archiwalne dotyczące tych organizacji są dość obfite, zawierają także dokumenty ochronek. Ochronki prężnie działających towarzystw w dużych miastach posiadają zazwyczaj akta pozwalające zanalizować różnorodne aspekty ich działalności. Dokumentacja tego rodzaju jest przechowywana na ogół w archiwach państwowych. Gromadzenie tej kategorii źródeł odbywało się zazwyczaj zgodnie z ogólnie obowiązującą zasadą pertynencji, czyli przynależności terytorialnej, opierającą się na poszanowaniu związków zespołów archiwalnych z terenem, na którym powstały. Zatem materiały do towarzystw dobroczynnych, w tym ochronek działających pod ich auspicjami, znajdują się w większości $\mathrm{w}$ archiwach państwowych oraz w podporządkowanych im oddzialach zamiejscowych.

Źródła archiwalne pokazują zakres działania ochronek. Analizę dokumentów w tym zakresie przeprowadziło kilku badaczy, którzy opracowali dzieje towarzystw dobroczynnych działających w XIX i na początku XX wieku w największych miastach Królestwa Polskiego. Obfitość materiałów archiwalnych, uzupełnianych przez inne typy źródeł, pozwoliła na omówienie działalności prowadzonych przez towarzystwa dobroczynne ochronek w Warszawie, Lublinie, Łodzi, Kali-

8 AGAD, Rada Główna Opiekuńcza, sygn. 69, k. 4.

9 Tamże, sygn. 73, k. 18 v. 
$\mathrm{szu}^{10}$. W opracowaniach monograficznych towarzystw dobroczynnych przedstawiono formy działalności ochronek, realizację założeń pracy opiekuńczo-wychowawczej, problemy organizacyjne, finansowe, kadrowe. Zachowanie tego rodzaju dokumentacji umożliwia rekonstrukcję działalności ochronek w wielu innych miastach. Niektóre wydawane drukiem dokumenty, jak np. sprawozdania $z$ budowy oraz funkcjonowania ochronek, włączane do akt, są obecnie zdigitalizowane i dostępne w Internecie ${ }^{11}$. Istotną wartość mają materiały zgromadzeń zakonnych prowadzących ochronki oraz dokumentacja Kościołów i związków wyznaniowych, dotycząca spraw opiekuńczo-wychowawczych.

O ochronkach wspominano w dokumentach władz zaborczych o charakterze sprawozdawczym - w wydawanych drukiem dla poszczególnych guberni i dla miasta Warszawy „Obzorach” oraz „Pamiatnych Kniżkach”. Notatki tam zawarte są bardzo lapidarne, ale potwierdzają funkcjonowanie placówek. Przydatnym źródłem mogą być różnego rodzaju kalendarze, w tym warszawski „Kalendarz Informacyjno-Encyklopedyczny”. Krótkie wzmianki o istnieniu ochronek znaleźć można także w publikowanych na przełomie XIX i XX wieku pracach dotyczących geografii Królestwa, w których zamieszczano informacje o funkcjach pełnionych przez ośrodki miejskie, w tym funkcji opiekuńczej, realizowanej m.in. w placówkach opieki nad dziećmi pracujących rodziców. Podkreślano realizację tego rodzaju zadań i funkcji nie tylko w największych miastach jak Warszawa, Lublin, Piotrków, Kielce, Łódź, ale także w mniejszych ośrodkach jak np. Sosnowiec, Zgierz, Żyrardów ${ }^{12}$.

Ważną kategorią źródłową są wypowiedzi polskich społeczników $\mathrm{i}$ intelektualistów, którzy propagowali zakładanie zakładów opiekuńczo-wychowawczych dla dzieci ${ }^{13}$. Działaczom społecznym w Kró-

10 Por. H. Markiewiczowa, Dziatalność opiekuńczo-wychowarwcza Warszawskiego Towarzystwa Dobroczynności 1814-1914, Warszawa 2002; C. Kępski, Lubelskie Towarzystwo Dobroczynności (1815-1952), Lublin 2011; J. Sosnowska, Dziatalność socjalna i opiekuńczo-wychowawcza Eódzkiego Chrześcijańskiego Towarzystwa Dobroczynności (1885-1940), Łódź 2011.

11 Zob. np. Sprawozdanie Komitetu budowy nowego gmachu Ochrony Katolickiej w Pabjanicach, Pabianice 1910; Sprawozdanie Warszawskiego Towarzystwa Dobroczynności za rok 1907, Warszawa 1908.

12 L. de Verdmon-Jacques, Krótka gieografja Królestwa Polskiego, Warszawa 1912.

13 Szerzej piśmiennictwo w tym zakresie omawia K. Jakubiak, Poczatki polskiej pedagogiki przedszkolnej, „Edukacja Elementarna” 2015, nr 4, s. 109-118. 
lestwie znany był ważny tekst Augusta Cieszkowskiego $O$ ochronach wiejskich, opublikowany w 1842 roku na łamach „Biblioteki Warszawskiej"14. Nieco miejsca poświęcił ochronkom w wydanym w 1861 roku piśmie o problemach wychowania dr Ludwik Natanson, który przedstawiał dylematy typowe dla ówczesnego namysłu o instytucjonalnych formach opieki nad małymi dziećmi. Ubolewał, że żłobki i ochronki, zastępując opiekę matczyną nad dzieckiem, „niweczą w znacznej mierze części uczucia rodzinne i zwalniają węzły rodziny, która jest podstawą społeczeństwa”. Pisał, że mimo pozytywnych aspektów działalności, są one „złem, chociaż często złem koniecznem, zastępującem coś gorszego" ${ }^{15}$. Jednocześnie podkreślał ich pozytywną rolę w wychowaniu fizycznym, moralnym i umysłowym. "Jako środki do rozwijania umysłu powinny tu służyć: rozmowa, zabawa, okazywanie przedmiotów codziennego życia w naturze lub obrazach. Pacierze i śpiewy nabożne niech będą jedyną nauką"16.

Istotne znaczenie $\mathrm{w}$ propagowaniu idei ochronek miały wypowiedzi ziemianina Adama Goltza, autora pracy Ochronki wiejskie oraz dwóch rozdziałów poświęconych opiece nad dziećmi, a umieszczonych w książce zbiorowej Niedole dziecięce. Goltz podkreślał rolę ochronki jako miejsca opieki i stymulowania wszechstronnego rozwoju dziecka. Pisał:

Ochrona nie jest szkołą, w której nauczyciel wykłada naukę w systematyczne ujęte formy. Osoba ochronie przewodnicząca chwytać winna umiejętnie z codziennego życia każdą sposobność, każde nowe dla umysłu dzieci wrażenie, każdą budzącą się w nich ciekawość, każde zapytanie, aby z nich wyprowadzić naukę [...]. Oto sprzęt każdy już być może przedmiotem zajmującej nauki. [...] Każda wycieczka w pole, każdy kamyk, roślina, drzewo [...] otwiera szerokie pole rozmowy ${ }^{17}$.

$\mathrm{Na}$ inne aspekty zwracał uwagę Ludwik Górski, którego praca z 1899 roku, dotycząca ochronek wiejskich, adresowana głównie do zamożniejszych ziemian, miała zachęcić ich do zakładania tego ro-

Autor przedstawia także prace zagranicznych autorów, których w niniejszym artykule nie analizuję.

14 A. Cieszkowski, O ochronach wiejskich, „Biblioteka Warszawska” 1842, t. 1, s. $367-412$.

15 L. Natanson, Urywki w kwestyi wychowania, Warszawa 1861, s. 28-29.

16 Tamże, s. 29.

17 A. Goltz, Ochronki wiejskie, Warszawa 1861, s. 26-27. 
dzaju placówek. Górski podkreślał dobroczynne znaczenie ochronek, ale akcentował także ich ekonomiczny wymiar - zarówno w kontekście korzyści dla właścicieli folwarków, jak i dla robotników rolnych. Podawał konkretne wskazówki natury prawnej i organizacyjnej, przydatne ziemianom pragnącym podjąć taką inicjatywę. Zdecydowanie mniej uwagi poświęcał pedagogicznym aspektom pracy z dziećmi i korzyściom płynącym dla wychowanków z pobytu w placówce. Nawet pisząc o zabawach dzieci podkreślał ich utylitarny charakter, nie dostrzegał ich autotelicznej wartości. Podkreślał konieczność respektowania całkowitego zakazu prowadzenia nauki czytania i pisania, uważał za niewskazane podawanie dzieciom posiłków, ponieważ podniosłoby to koszty utrzymania ochronki. Nie widział potrzeby unowocześnienia ani celów wychowania, ani sposobów kształcenia pracujących w nich wychowawczyń. Zaznaczał, że

dozorczynią może być kobieta prosta, ale religijna, roztropna i mająca zamiłowanie do dzieci. Nie ma potrzeby wymagać od niej kwalifikacyi naukowej wyższej nad tę, jakiej potrzeba aby dzieci pacierza dobrze nauczyć i do robót ręcznych powoli wprawiać. Roztropna ochroniarka powinna rozwijać w dzieciach zasadnicze pojęcia o dobrem i złem, o prawdzie i fałszu, o obowiązkach względem Boga i ludzi, a zarazem przyzwyczajać do posłuszeństwa, porządku i pracy ${ }^{18}$.

Cennymi źródłami są opublikowane w 1906 roku wartościowe i oparte na ówczesnych ustaleniach pedagogicznych prace dotyczące zakładania i prowadzenia ochronek, autorstwa Marii Weryho i Stefanii Marciszewskiej ${ }^{19}$.

Bardzo interesującą kategorią źródeł są listy i wspomnienia. Warto poddać analizie korespondencję działaczy społecznych zaangażowanych w zakładanie ochronek. O obecności tego tematu źródłach epistolograficznych świadczyć moga choćby listy ojca Honorata Koźmińskiego do członkiń zgromadzeń bezhabitowych ${ }^{20}$. Bezcenne informacje na temat działalności ochronek znaleźć można w pa-

L. Górski, Ochronki wiejskie, Warszawa 1899, s. 16.

Por. M. Weryho, W sprawie ochron. Wskazówki dla osób zakładajacych ochrony wiejskie, Warszawa 1906; S. Marciszewska, Rady i wskazówki dla kierujacych ochronami, Warszawa 1906.

Por. np. H. Koźmiński, Pisma, t. 5: Listy do Zgromadzenia Sióstr Stużek Najświętszej Maryi Panny Niepokalanej, 1884-1916, oprac. H.I. Szumił, Warszawa 1997, s. 92-93. 
miętnikach, dziennikach i wspomnieniach, z których część wydanych jest drukiem, część pozostaje w zasobach archiwalnych. Chodzi tu o źródła memuarystyczne, autorstwa założycieli, pracowników i wychowanków ochronek. I tak na przykład wiele interesujących informacji na temat okoliczności założenia i prowadzenia ochronek zawarł w swoich wspomnieniach ksiądz Wacław Bliziński, który był inicjatorem szeregu instytucji samopomocowych w Liskowie - wsi uznawanej za wzorcową pod względem organizacji życia społecznego i gospodarczego. Opisywał trudności związane z prowadzeniem ochronek w Liskowie i innych okolicznych wsiach, wynikające zarówno z początkowej niechęci i niezrozumienia lokalnej społeczności, jak i szykan ze strony władz zaborczych. Trudnym problemem była inwigilacja i niechęć lokalnych władz i policji. „Dzieci, niestety, musiały uczyć się trochę krętactwa, bo gdy wchodził żandarm, chowały książki, kajety, a niby uczyły się śpiewać, pacierza, gimnastyki”"

Wartościowe informacje na temat znaczenia pobytu w ochronkach w życiu ich wychowanków przynoszą wspomnienia z dzieciństwa. Prócz materiałów drukowanych ${ }^{22}$, warto sięgnąć do wspomnień przechowywanych w archiwach. Na przykład w Archiwum Naukowym Instytutu Etnologii i Antropologii Kulturowej Uniwersytetu Łódzkiego zgromadzono zapisy wywiadów przeprowadzonych w latach 60-80. XX wieku z mieszkańcami Łodzi, we wspomnieniach których wiele uwagi poświęcono realiom życia społecznego miasta na początku XX wieku. Informacje w nich zawarte dotyczą m.in. kwestii działań opiekuńczo-wychowawczych wobec dzieci, w tym działalności ochronek ${ }^{23}$. I tak, urodzony w rodzinie robotniczej na początku XX wieku łodzianin wspominał: „Jako dziecko chodziłem do ochronki, ufundowanej przez Scheiblerów. $\mathrm{Na}$ śniadanie dawali kawę mleczną niesłodzoną, chleb suchy lub z marmoladą. Przyjmowali dzieci rodziców znajdujących się w warunkach wyjątkowo trudnych lub dzieci wdów"24.

21 W. Bliziński, Wspomnienia z mego życia i pracy, oprac. G. Waliś, Kalisz 2003, s. 48.

22 Por. Robotnicy piszą. Pamiętniki robotników, oprac. Z. Mysłakowski, F. Gross, Kraków 1938, s. 110.

23 Por. Archiwum Naukowe Instytutu Etnologii i Antropologii Kulturowej Uniwersytetu Łódzkiego, sygn. B 1610, B 1620, B 1847.

24 Tamże, sygn. B 1610, k. 1. 
Wielką wartość dla badań nad przeszłością instytucji opiekuńczo-wychowawczych w dobie zaborów mają czasopisma i codzienne gazety. Często zamieszczano w nich sprawozdania z działalności konkretnych placówek, podawano informacje na temat budżetu, założeń organizacyjnych, warunków lokalowych i bytowych, rzadziej pisano o metodach i formach pracy. Szczegółowo i wszechstronnie zagadnienia te omówiła Stefania Walasek ${ }^{25}$. Warto w tym miejscu pokrótce przypomnieć, że kwestie dotyczące działalności ochronek pojawiały się m.in. na łamach czasopism pedagogicznych, higienicznych i medycznych, społeczno-kulturalnych. Opisywano np. warunki funkcjonowania i metody pracy wychowawczej stosowane w placówkach uznawanych za wzorcowe ${ }^{26}$. O problemach organizacyjnych i wychowawczych, programach nauczania, metodach i środkach dydaktycznych stosowanych w ochronkach pisano na łamach prasy kobiecej, m.in. w czasopismach redagowanych i wydawanych przez działaczki ruchu ziemianek. O kwestiach tych pisano wiele w czasopismach „Świat Kobiecy” i „Polski Łan”, rzadziej na łamach „Ziemianki”. Krótkie informacje o zakładaniu i działalności ochronek zamieszczano także w lokalnej prasie w każdej guberni. Donoszono o tym na łamach gazet w wielkich miastach - np. w "Gazecie Warszawskiej”, „Kurierze Warszawskim”, „Dzienniku Łódzkim”, łódzkim „Rozwoju”, ale także w periodykach wydawanych w mniejszych ośrodkach. I tak na przykład w 1902 roku w „Echach Płockich i Łomżyńskich" pisano o inicjatywie w Płońsku:

Dzięki zabiegom pp. Młyńskiego i Kalinowskiego w początkach października zostanie otworzona w mieście naszem ochronka prywatna, do której przyjmowane będą dzieci z uwzględnieniem stanu materialnego ich rodziców. Kierowniczką ochronki będzie p. Dobrowolska, która uzyskała na to pozwolenie odpowiedniej władzy ${ }^{27}$.

Warto również pamiętać o przydatności w badaniach historyczno-oświatowych źródeł ikonograficznych, w tym przede wszystkim fotografii. Upowszechnienie fotografii sprawiło, że stała się ona waż-

25 Por. S. Walasek, Opieka i wychowanie matego dziecka na tamach czasopism przetomu XIX i XX wieku, Wrocław 2015.

26 Por. np. Silva Rerum, „Kronika Rodzinna” 1881, t. 9, s. 606; Nowa ochrona, „Przegląd Pedagogiczny” 1901, nr 10, s. 128-130.

27 Z naszych okolic, „Echa Płockie i Łomżyńskie” 1902, nr 77, s. 4. 
ną kategorią źródeł w odniesieniu do różnych zbiorowości i sytuacji społecznych, także do badań nad dziejami instytucji edukacyjnych, opiekuńczych i wychowawczych. Niestety, w większości zachowane fotografie ochronek mają charakter zdjęć wykonywanych przy szczególnych okazjach, dzieci i wychowawczynie ustawiano w określonym porządku, często na fotografii uwiecznieni byli protektorzy placówki. Tego rodzaju fotografie, przechowywane w zbiorach archiwalnych, mają charakter statyczny, dorośli i dzieci są poważni i skupieni. $\mathrm{Na}$ przełomie XIX i XX wieku pojawiły się także fotografie wykonywane podczas codziennych zajęć dzieci, co pozwala lepiej poznać realia ochronek. Zamieszczano także je na łamach gazet i czasopism, jak na przykład w „Tygodniku Ilustrowanym”28.

\section{Opinia publiczna wobec ochronek w świetle publicystyki społecznej}

Interesującą kategorię źródeł do analizy problemów związanych z funkcjonowaniem placówek dla małych dzieci z rodzin niezamożnych lub pracujących zawodowo rodziców stanowi publicystyka społeczna. Artykuły i teksty polemiczne, dążące do możliwie obiektywnego przedstawienia problemu, oraz świadomie subiektywne wypowiedzi publicystów zamieszczane na łamach czasopism miały popularyzować w szerokich kręgach odbiorców ideę instytucjonalnej opieki i wychowania. Od lat 60. XIX wieku tematyka ta pojawiała się w publicystyce społecznej systematycznie. Początkowo wpisywała się w założenia pozytywistycznego programu „pracy u podstaw” i „pracy organicznej”, nawiązywała także do modelu tradycyjnej dobroczynności. W tekstach z ostatnich dekad XIX i pierwszych lat XX wieku stale podkreślano konieczność zapewnienia opieki dzieciom, które w czasie wykonywania przez rodziców pracy były narażone na wypadki. Wiele pisano o tych kwestiach m.in. na łamach „Kroniki Rodzinnej”. Podkreślano, że pozbawione opieki dzieci są zagrożeniem dla siebie i innych, np. wywołując pożary ${ }^{29}$. W podobnym duchu wypowiadano się również na łamach „Głosu” - w 1895 roku, podsumowując statystyki śmiertelności, pisano, że należy stale „Zwracać uwagę dobroczynności publicz-

28 Por. np. Dzieci tódzkie, „Tygodnik Ilustrowany” 1907, nr 12, s. 252.

29 Por. Ochrony dla wiejskich dzieci, „Kronika Rodzinna” 1893, nr 9, s. 257-258; Ochrony dziecięce, „Przegląd Katolicki” 1895, t. 33, s. 374; Silva Rerum, „Kronika Rodzinna” 1883, nr 17, s. 541. 
nej na potrzebę opieki nad drobnemi dziećmi" ${ }^{30}$. Podobne wypowiedzi pojawiały się także w czasopismach pedagogicznych i medycznych ${ }^{31}$.

Organizację instytucjonalnej opieki nad dziećmi uważano za moralny obowiązek społeczeństwa oraz konieczność dyktowaną względami ekonomicznymi i demograficznymi. Zakładanie ochronek przedstawiano jako formę wspierania ubogich rodzin na wsiach i w miastach, umożliwiającego pracę zarobkową rodzicom. Drugim zasadniczym celem ochronek miało być, w opinii publicystów omawianego okresu, zapewnienie opieki dzieciom zagrożonym „złym wpływom ulicy”. Pisząc o działalności ochronek, stale podkreślano ich funkcję opiekuńczą, wychowawczą, ale także prewencyjną. Przekonywano, że dzieci ubogich, pracujących rodziców są pozostawione „bez żadnego dozoru i kierunku, tarzają się moralnie i materialnie w rynsztoku, wprowadzając w czyn najdziksze pomysły"32. O tym aspekcie opieki nad kilkuletnimi dziećmi wielokrotnie pisano na łamach prasy wyznaniowej. I tak, np. w „Przeglądzie Katolickim” i „Izraelicie” określano funkcję ochronek jako schronisk dla dzieci zagrożonych „moralnym zepsuciem” i upadkiem $^{33}$. Także w prasie codziennej publicyści pisali o znaczeniu edukacji kilkuletnich dzieci z zaniedbanych wychowawczo i społecznie środowisk. Na przykład na łamach „Łowiczanina” zaznaczano: „Kiedy dzieci przychodzą po raz pierwszy do ochronki, ich ulubioną zabawą jest zabawa w ztodzieja lub pijaka, co bije swa żonę ${ }^{34}$.

O znaczeniu ochronek wielokrotnie pisał Bolesław Prus, przekonując, że ich działalność przyczynia się do zmniejszenia skali śmiertelności dzieci i zapobiega ich demoralizacji ${ }^{35}$. Pisał m.in.

dzieci włościan nie mają opieki nawet w domach rodzicielskich. Ojciec i matka wychodzą na robotę, do karczmy lub na jarmark [...] potomstwo zaś ich zostaje w chacie samo, choć tak małe, że niejedno chodzić dobrze

Notatki statystyczne, „Głos” 1895, nr 5, s. 113.

Por. np. M. Roszkowski, O potrzebie zaktadania u nas ochron dla dzieci, „Zdrowie" 1903, nr 6-7, s. 625-627; Z Warszawskiego Towarzystwa Higienicznego, „Medycyna” 1904, nr 2, s. 32-35.

Groźne opuszczenie, „Kronika Rodzinna” 1890, nr 3, s. 68.

Por. J.G., Ochrony, „Przegląd Katolicki” 1864, nr 37, s. 582-585; nr 38, s. 599-603; Ochrony, „Izraelita” 1866, nr 17, s. 138.

Z Ochronki T-wa Wspomagania biednych, „Łowiczanin” 1911, nr 8, s. 2.

Por. C. Galek, Myśl pedagogiczna Bolestawa Prusa na tle pozytywizmu polskiego, Zamość 2005, s. 215-216. 
nie umie. Dzięki też temu systemowi porzucania dzieci na opiekę losu gazety nasze przepełnione są opisami straszliwych wypadków ${ }^{36}$.

Wypowiedzi publicystów upowszechniały ideę ochronek wśród opinii publicznej, pomagały też zbierać środki potrzebne do zakładania i prowadzenia kolejnych placówek.

U schyłku XIX wieku zaczęto dostrzegać możliwości organizacji ochronek na zasadach samopomocowych. Zdając sobie sprawę, że trudne warunki bytowe włościan nie ułatwiają organizacji placówek dla dzieci, pisano, że w przypadku braku we wsi szkoły, zajęcia w ramach ochronki mogłyby odbywać się po kolei w różnych chatach włościan, a także w ogrodzonych ogródkach i podwórkach. Mając świadomość trudności z pozyskaniem wykwalifikowanej ochroniarki, zachęcano do wyznaczenia opiekunki dzieci spośród mieszanek wsi ${ }^{37}$. Podobne rady kierowano do ludności miast. Stale podkreślano deficyt miejsc opieki nad dziećmi i jego fatalne konsekwencje. W 1904 roku w „Głosie” odnotowywano: „tak szczupła ilość ochron nawet w drobnej części nie odpowiada istotnym potrzebom ludności [...] ochronki dziecięce powinny znajdować się jeżeli już nie w każdej parafii, to przynajmniej w każdej gminie" 38 .

W publicystyce widoczne jest jak poważnym problemem była kwestia organizacji ochronek, do których uczęszczały dzieci różnych wyznań i narodowości, posługujące się różnymi językami. Miasta i miasteczka Królestwa Polskiego były przestrzenią przenikania się polskich, niemieckich, żydowskich, a także rosyjskich i innych wpływów kulturowych oraz etnicznych, co przekładało się również na opiekę i edukację. Wiele pisano o ochronkach żydowskich w Warszawie, które pracę wychowawczą realizowały w oparciu o program polonizujący i patriotyczny ${ }^{39}$. W latach 60 . i na początku lat 70 . w prasie żydowskiej podkreślano wartość ochronek dla wychowania i socjalizacji dziewcząt i chłopców. W tym okresie niektóre placówki miały „charakter szkół elementarnych” ${ }^{40}$. W ochronkach dla chłopców prowadzono naukę introligatorstwa i snycerstwa, a publicysta pod-

B. Prus, Kroniki, t. 3, oprac. Z. Szweykowski, Warszawa 1954, s. 392.

Por. O potrzebie u nas wiejskich ochron, „Przegląd Tygodniowy”1875, nr 27, s. 314.

Na widnokregach, „Głos” 1904, nr 15, s. 229.

Por. „Wieniec” 1862, nr 11, s. 1-4.

J.E., Korespondencja, „Izraelita” 1866, nr 10, s. 81. 
kreślał: „Z oczu pracującej dziatwy przemawiała inteligencja, zamiłowanie, a robota znamionowała biegłość" ${ }^{41}$. Nierzadko do ochronek uczęszczały dzieci różnych wyznań i narodowości. Ale nawet gdy placówka była przykładem zgodnej współpracy, stawała się czasem przedmiotem krytyki, oskarżeń o wynaradawianie dzieci i narażanie ich na indoktrynację religijną ${ }^{42}$.

Na przełomie XIX i XX wieku na łamach czasopism bardzo wiele pisano o pedagogicznym kontekście działalności ochronek. $Z$ perspektywy wychowawczej, zdrowotnej, higienicznej i demograficznej podejmowano zagadnienia organizacji i stanu higienicznego placówek oraz rozwoju ich podopiecznych. O ile w ostatnich dekadach wieku XIX podkreślano niemal wyłącznie pozytywne aspekty działalności ochronek, to na początku XX wieku na łamach prasy coraz częściej zwracano uwagę na różnego rodzaju nieprawidłowości. Wielu publicystów uważało za konieczne modernizowanie placówek i reformę systemu pracy wychowawczej. Założycielom placówek zarzucono kierowanie się względami ekonomicznymi przy określaniu poziomu ich finansowania, umieszczanie zakładów w ciasnych, niedogrzewanych pomieszczeniach, zatrudnianie niewłaściwie przygotowanych opiekunek. Nade wszystko krytykowano niedostateczną troskę o metody pracy z dziećmi, opieranie działań wychowawczych na wpajaniu posłuszeństwa, pracowitości, poczucia obowiązku ${ }^{43}$. Publicyści o przekonaniach lewicowych uważali ochronki za placówki oparte na patriarchalnym systemie traktowania ubogich, wytwarzające mechanizmy socjalizacyjne, które prowadziły do narzucania wychowankom określonych postaw i zachowań oraz wyznaczania im z góry miejsca w hierarchii społecznej. Wyrażali opinie o niebezpieczeństwie wpisania opieki nad dziećmi z ubogich środowisk w hierarchię, w której wychowankowie i ich rodziny, uznani za słabszych i wymagających kontroli, pozbawieni byli podmiotowości i sprawczości.

Krytyczne opinie publicystów były w niemałej mierze uzasadnione. Oceniając system opieki w ochronkach, trzeba jednak uwzględnić wa-

41 Pogadanki, „Izraelita” 1872, nr 27, s. 218.

42 Por. List do redakcji, „Zwiastun Ewangeliczny” 1904, nr 3, s. 85.

43 Por. J. Weznaki, Na widowni, „Głos” 1896, nr 8, s. 183; L. Krzywicki, Uspotecznienie pieczy macierzyńskiej, w: tenże, Dzieta, t. 5, red. A. Osiadacz-Molska, Warszawa 1960, s. 153. G. [J. Korczak], Tandeta dobroczynna, „Głos” 1904, nr 11, s. 163. 
runki, w jakich one funkcjonowały. Powstawały z inicjatywy społecznej, były niemal całkowicie pozbawione wsparcia władz administracyjnych, które często utrudniały ich działalność edukacyjną. Na początku XX wieku liczba placówek była znacząca, widoczny był też stały postęp w jakości pracy dydaktyczno-wychowawczej. Zmiany w organizacji, finansowaniu, metodach, celach i zadaniach ochronek wymagały reformy całego systemu i mogły być zrealizowane w odrodzonym państwie. Doświadczenia zdobyte przez działaczy społecznych w zakładaniu i prowadzeniu placówek dla dzieci w okresie zaborów pomogły w budowaniu systemu przedszkolnego w II Rzeczypospolitej.

\section{Podsumowanie}

Przywołane $\mathrm{w}$ artykule źródła archiwalne i drukowane mają wysoką wartość w badaniach nad dziejami ochronek. Archiwalia instytucjonalne, uzupełniane przez inne kategorie źródeł rękopiśmiennych (listy, pamiętniki) oraz źródła drukowane, w tym m.in. czasopiśmiennictwo i rozprawy pedagogiczne, umożliwiają przeprowadzenie dogłębnej analizy działalności ochronek w Królestwie Polskim w okresie zaborów. Bogaty jest dorobek polskiej historiografii w zakresie różnych aspektów działań opiekuńczo-wychowawczych podejmowanych wobec małych dzieci w zaborze austriackim i pruskim $^{44}$. Wartościowe opracowania historyczno-pedagogiczne, dotyczące funkcjonowania ochronek na tych obszarach, pozwalają dokonać porównań i wskazać analogie w zakresie warunków i metod pracy oraz opisać wzajemną recepcję idei edukacyjnych. Daje to możliwość odtworzenia roli ochronek w procesie budowania systemu opieki i wychowania dzieci na ziemiach polskich w dobie nowoczesności.

\section{Bibliografia}

Archiwum Główne Akt Dawnych, Kancelaria Generał-Gubernatora Warszawskiego, sygn. 8012.

Archiwum Główne Akt Dawnych, Rada Główna Opiekuńcza, sygn. 60-73.

44 Por. m.in.: Opieka nad dzieckiem w Galicji, red. A. Meissner, Rzeszów 2002; A. Haratyk, Udziat spoteczeństwa galicyjskiego w opiece nad dziémi ubogimi i osieroconymi (1867-1914), Kraków 2007; M. Loyola-Opiela, Integralna pedagogika przedszkolna w systemie wychowania Edmunda Bojanowskiego: kontynuacja i zmiana, Lublin 2013. 
Archiwum Naukowe Instytutu Etnologii i Antropologii Kulturowej Uniwersytetu Łódzkiego, sygn. B 1610, B 1620, B 1847.

Archiwum Państwowe w Łodzi, Rząd Gubernialny Piotrkowski, Kancelaria Prezydialna, sygn. 294.

Bliziński W., Wspomnienia z mego życia i pracy, oprac. G. Waliś, Kaliskie Towarzystwo Przyjaciół Nauk, Kalisz 2003.

Bołdyrew A., Spoteczeństwo Królestwa Polskiego wobec patologii spotecznych w latach 1864-1914, Wydawnictwo UŁ, Łódź 2016.

Cieszkowski A., O ochronach wiejskich, „Biblioteka Warszawska”1842, t. 1.

Dzieci tódzkie, „Tygodnik Ilustrowany” 1907, nr 12.

E.J., Korespondencja, „Izraelita” 1866, nr 10.

G. [Korczak J.], Tandeta dobroczynna, „Głos” 1904, nr 11.

Galek C., Myśl pedagogiczna Bolestawa Prusa na tle pozytywizmu polskiego, Wyższa Szkoła Zarządzania i Administracji w Zamościu, Zamość 2005.

Goltz A., Ochronki wiejskie, Księgarnia Celsa Lewickiego, wyd. 2, Warszawa 1861.

Górski L., Ochronki wiejskie, Drukarnia Noskowskiego, Warszawa 1899.

Groźne opuszczenie, „Kronika Rodzinna” 1890, nr 3.

Haratyk A., Udziat spoteczeństwa galicyjskiego w opiece nad dziećmi ubogimi i osieroconymi (1867-1914), Oficyna Wydawnicza Impuls, Kraków 2007.

J.G., Ochrony, „Przegląd Katolicki” 1864, nr 37, 38.

Jakubiak K., Poczatki polskiej pedagogiki przedszkolnej, „Edukacja Elementarna” 2015, nr 4.

Kalendarz Informacyjno-Encyklopedyczny na rok przestęny 1904, Warszawa 1904.

Kępski C., Lubelskie Towarzystwo Dobroczynności (1815-1952), Wydawnictwo KUL, Lublin 2011.

Koźmiński H., Pisma, t. 5: Listy do Zgromadzenia Sióstr Stużek Najświętszej Maryi Panny Niepokalanej 1884-1916, oprac. H.I. Szumił, Instytut B1. Honorata Koźmińskiego, Warszawa 1997.

Krzywicki L., Uspotecznienie pieczy macierzyńskiej, w: tenże, Dzieła, t. 5, red. A. Osiadacz-Molska, PWN, Warszawa 1960.

List do redakcji, „Zwiastun Ewangeliczny”1904, nr 3.

Loyola-Opiela M., Integralna pedagogika przedszkolna w systemie wychowania Edmunda Bojanowskiego: kontynuacja i zmiana, Wydawnictwo KUL, Lublin 2013.

Marciszewska S., Rady i wskazówki dla kierujacych ochronami, Druk Piotra Laskauera i S-ki, Warszawa 1906.

Markiewiczowa H., Dziatalność opiekuńczo-wychowarwcza Warszarwskiego Towarzystwa Dobroczynności 1814-1914, Wydawnictwo APS, Warszawa 2002.

Mazurek M.H., Powstanie i rozwój ukrytych zgromadzeń bt. Honorata Koźmińskiego w latach 1874-1908, oprac. H.I. Szumil, Wydawnictwo Diecezjalne i Drukarnia, Sandomierz 2009.

Na widnokregach, „Głos” 1904, nr 15.

Natanson L., Urywki w kwestyi wychowania, Wydawnictwo H. Natansona, Warszawa 1861. 
Notatki statystyczne, „Głos” 1895, nr 5.

Nowa ochrona, „Przegląd Pedagogiczny” 1901, nr 10.

O potrzebie u nas wiejskich ochron, „Przegląd Tygodniowy” 1875, nr 27.

Ochrony dla wiejskich dzieci, „Kronika Rodzinna” 1893, nr 9.

Ochrony dziecięce, „Przegląd Katolicki” 1895, t. 33.

Ochrony, „Izraelita” 1866, nr 17.

Opieka nad dzieckiem w Galicji, red. A. Meissner, Wydawnictwo Uniwersytetu Rzeszowskiego, Rzeszów 2002.

Pietkiewicz Z., Opieka spoteczna. Dzieci, „Prawda” 1900, nr 47.

Pogadanki, „Izraelita” 1872, nr 27.

Prus B., Kroniki, t. 3, oprac. Z. Szweykowski, PIW, Warszawa 1954.

Robotnicy piszq. Pamiętniki robotników, oprac. Z. Mysłakowski, F. Gross, Księgarnia Powszechna, Kraków 1938.

Roszkowski M., O potrzebie zaktadania u nas ochron dla dzieci, „Zdrowie” 1903, nr 6-7.

Silva Rerum, „Kronika Rodzinna” 1881, t. 9.

Silva Rerum, „Kronika Rodzinna” 1883, nr 17.

Sosnowska J., Dziatalność socjalna i opiekuńczo-wychowawcza Eódzkiego Chrześcijańskiego Towarzystwa Dobroczynności (1885-1940), Wydawnictwo UŁ, Łódź 2011.

Sprawozdanie Komitetu budowy nowego gmachu Ochrony Katolickiej w Pabjanicach, Pabianice 1910.

Sprawozdanie Warszawskiego Towarzystwa Dobroczynności za rok 1907, Warszawa 1908.

Verdmon-Jacques de L., Krótka gieografja Królestwa Polskiego, M. Arct, Warszawa 1912.

Walasek A., Opieka i wychowanie matego dziecka na tamach czasopism przetomu XIX i XX wieku, Oficyna Wydawnicza Atut - Wrocławskie Wydawnictwo Oświatowe, Wrocław 2015.

Weryho M., W sprawie ochron. Wskazówki dla osób zaktadających ochrony wiejskie, Gebethner i Wolff, Warszawa 1906.

Weznaki J., Na widowni, „Głos” 1896, nr 8.

„Wieniec” 1862, nr 11, s. 1-4.

Z naszych okolic, „Echa Płockie i Łomżyńskie” 1902, nr 77.

Z Ochronki T-wa Wspomagania biednych, „Łowiczanin” 1911, nr 8.

Z Warszawskiego Towarzystwa Higienicznego, „Medycyna” 1904, nr 2.

\section{ADRES DO KORESPONDENCJI}

\section{Dr Aneta Bołdyrew}

Uniwersytet Łódzki

Wydział Nauk o Wychowaniu, Katedra Historii Wychowania i Pedeutologii bow0@poczta.onet.pl 